\title{
SPATIAL ANALYSIS OF POLITICAL CAPITAL CITATION USING REMOTE SENSING AND GIS; A CASE STUDY OF LOKOJA \\ *DUKIYA, J. J. ${ }^{1}$ and OKHIMAMHE, A. A. ${ }^{2}$ \\ http://dx.doi.org/10.4314/ejesm.v6i3.15
}

\begin{abstract}
Received 22nd March 2013; accepted 21st May 2013

Lokoja town, the Kogi state capital is located at the Niger-Benue confluence in the south central part of Nigeria which is about $170 \mathrm{~km}$ from the Federal Capital Territory (FCT) Abuja. The town has experience tremendous urbanization changes in its strait location within the elongated Patti Hill and the River Niger - Benue confluence which is a potential zone of conflict between man and the environment. This study therefore uses the Remote Sensing and GIS technique in assessing the pattern of urbanization growth around the confluence area by generating a land-use/land-cover map from the satellite imageries of Landsat (TM/ETM) of 1987 and 2001 using Arc View 3.3 and Idrisi 32. The study find out that the sandwiching of the town actually support the doctrine of environmental determinism as against the environmental possibilism as new developments are forced toward Kabba and Ganaja roads. River bank encroachment and ecological devastation is also very obvious from the image analysis. Land reclamation for various land uses is on the increase along the Niger River especially along Filele. The image analysis and even visual observation reveal that Patti hill is being eroded by all forms of human development activities with evidences of landslides. This study also shows that peri-urban development is on the increase where agricultural farm stead is becoming urbanized as seen all around Niger barracks. The study therefore recommended that RS and GIS should be a major tool in spatial urbanization management and in the citation of any political capital in the country.
\end{abstract}

Key Words: Confluence Area, Land/Use, Remote Sensing, Terrain, Urbanization.

\section{Introduction}

River confluence areas all over the world are known to offer spectacular environmental attractions to people and have therefore been the focus of varied aspects of human activities. But Obateru (2004) opine that axiomatically, the founding and growth of cities do not only rest on the physical resources of its site but also on the regional framework of its physiographic which either aids or hinders its internal and external functional efficiency,

In the last seven years, urbanization activities in Lokoja have being on the increase and this can be attributed to her state capital status in 1991. The core area of the town is sandwiched between the Niger River valley and the elongated Patti Hill to the west. According to Obateru (2004), the topography of the site and environs of a capital should not be rough or rugged, or else there would be insufficient building space which would result in high land values and inhibit efficient land use organization and economical provision of social infrastructure and public utilities system. The study specifically assesses the effect of the natural terrain on the urbanization pattern and its effect on the shoreline area of the river confluence

${ }^{1}$ Department of Urban and Regional Planning, Federal

University of Technology, Minna,Nigeria.

${ }^{2}$ Department of Geography, Federal University of Technology,

Minna, Nigeria.

*Corresponding Author:duksat2000@futminna.edu.ng environment and the flood vulnerability of the developed areas bordering the river bank.

Most urban areas of developing countries were hitherto experiencing unprecedented growth in their population, the phenomenon commonly referred to as urbanization, which in this study can be said to be the proportion of urban population relative to the total population of a region.

\section{Conceptual Framework}

The world's political and environmental landscape has changed significantly and the critical issues of equity and environment and raised important ethical considerations regarding human-environment relationships (Langhelle, 1999) that remain highly relevant. The failure to stem the tide of unsustainable human activities can be linked to both ineffective institutions and a general lack of political will on the part of governments and citizens at multiples scales. Ononiwu (1990) is also of the opinion that in the management of river basin and cost effective way of managing the patterns of urban and rural environment is by the combination of satellite imageries and terrain model.

When the total impervious area of a watershed is over 25 percent, serious degradation of 
downstream ecosystems is said to have occurred (Department of the Interior, University of Wisconsin, 2002). The total amount of impervious area varies by the type of development. In great lakes region (USA) also, two river conservation and management projects was carried out in which a GIS framework that was developed cooperatively by personnel at the University of Michigan, U.S. Geological Survey, and the Illinois, Michigan, and Wisconsin Departments of Natural Resources was used (USGS 2004a).

The location of Lokoja around the NigerBenue and the high rate of urbanization has impacted greatly on the ecological setting of the river course which also leads to the resent disastrous flooding activities of October 2012.

\section{Aim and Objectives of the Study}

The aim of this project is to assess the effect of physical environmental factors on Kogi State capital development at the Niger-Benue confluence area with a view of proffering a GIS based planning technique for managing the town through the following objectives.
1. Examine the major physical factors that seem to dictate the pattern of growth in the town,

2. examine and map out the land-use/land cover changes over the area,

3. examine the pattern of the urbanization growth and development of the town,

4. examine the environmental induced degradation with a view of proffering ways of mitigating environmental problems already created by the man- made developmental activities.

\section{Study Area}

Lokoja the Kogi state capital is located on Latitude: $07^{\circ} 50^{\prime} \mathrm{N}$ and Longitude: $06^{\circ} 44^{\prime} \mathrm{E}$ and with a total land coverage of about 3179.7189 sq.km. The town is located at the River NigerBenue confluence and is in the south central part of Nigeria. The town is about $170 \mathrm{~km}$ from the Federal Capital Territory (FCT), Figure.1 shows the location of the town in relation to the River Niger course.

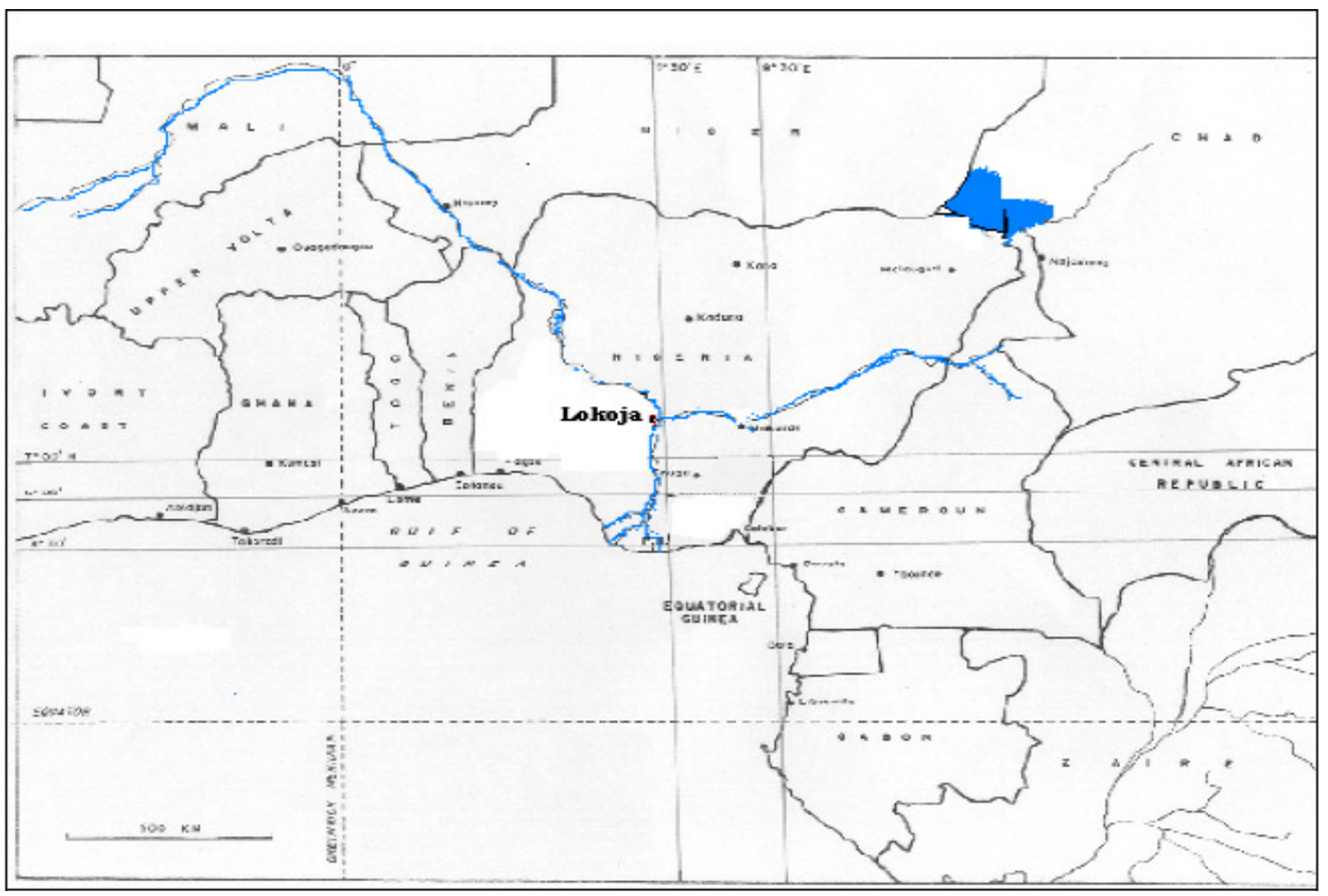

Figure 1 Map of West Africa showing Lokoja the confluence town of Nigeria

\section{The people and occupation of the area}

Kogi state was created out of Kwara and Benue state in the year 1991, with her state capital at Lokoja. This confluence town where River Niger and Benue meet used to be a local government headquarters that later transformed 
into a state capital. It is therefore not for fun that vehicle plate numbers celebrate Kogi as the confluence state. This transformation has brought in a lot of changes to the town. In 1859 a British trading and missionary settlement was founded in Lokoja and by 1987, Lokoja had a population estimate of 45,600 while the 1991 population census, estimated was 82,483 with 15,741 households. The town used to be a regional distribution center for agricultural produce (chiefly cotton) and food-processing industries even before the nearby Ajaokuta iron ore mill.

The inhabitants of Lokoja are mainly multilingual and an average young boy has a fair comprehension of Hausa, Yoruba and Pidgin English. Most of the people from the east and central senatorial district of the state speaks Igala and Ebira respectively. Etymologist say, Lokoja is probably derived from a Yoruba phrase, 'Ilukojo' which is translated as the "collection of settlements". Kogi State has 21 local governments with numerous ethnic groups that are fully represented in the state headquarter which comprises of: the Bassa, the Nupes, the Oworo, the Ebiras, the Igala, the Okun and many others.

\section{The Historical Background}

Historically, the famous British explorer Mungo Park is said to have visited Lokoja in 1775 and that other missionaries, notably Dr. Balfour Baike, subsequently followed his trail in discovering and re-discovering the settlement. The homes, offices and warehouses eventually put up by these explorers transformed Lokoja from a village into a bustling commercial town of that era. The town was re-discovered by William Balfour who was a British consul of the interior in 1860. In 1868 the consulate was abolished and the settlement was left wholly to commercial interests. In 1879 Sir George Dashwood Taubman formed the Royal Niger Company, and in 1886 the company made Lokoja its military centre, and on the transfer of the company's territories to the Crown it remained for a time the capital of Northern Nigeria. In 1902 the political capital of the protectorate was shifted to Zungeru in the province of Zaria, but Lokoja remains the commercial centre. In the absence of any central native authority the province is entirely dependent for administration upon British initiative. It was divided into four administrative divisions, the British and native courts of justice were also established. It is here that Sir Frederick Lugard was sworn in as the first Governor of the Northern
Protectorate. Although treaties were signed with traditional rulers from far north such as Sokoto by 1885 , actual British control was confined to the coastal area and the immediate vicinity of Lokoja until 1900. The Royal Niger Company had access to the territory from Lokoja extending along the Niger and Benue rivers above their confluence. After the colonial administration had pulled out from the town, Lokoja lapsed into obscurity for several decades. But this historic settlement has been regaining her socio-political status since August 27, 1991 when it was made the capital of Kogi State (Maurice 2005).

\section{Urbanization Trend in Lokoja}

The growth of Lokoja can actually be traced back to the exploration work of Mungo Park who started exploration of River Niger in 1775. And his work was consolidated by William Baikie in 1854 by the establishment of a permanent model farm centre and transitional trading activities for colonial European firms in 1860s which then attracted other immigrants. Also in 1904, the town was made the headquarters of the then Northern protectorate before the headquarter ship was transferred to Zungeru and finally to Kaduna.

Lokoja, the confluence town of Nigeria has experienced tremendous changes spatially and socio-economically since it has been made the state capital of Kogi State, see table 1 for the phases of growth of the town. The amalgamation of some parts of former Benue and Kwara states to form the present Kogi State actually attracted over 20,000 civil servants excluding their dependants into Lokoja town within a period of less than five (5) years. Many other self employed people and private organizations also migrated into the town in search of exploitable economic opportunities. In fact, the town is believed to have a population growth rate of about $6.0 \%$ within the first few years of the state creation.

\section{Urbanization Impacts on Aquatic Resources}

The unintended results of development attributable to increases in total impervious area in the built up town and cities include:

I. Reduction in natural storage and retention of rain and snowmelt

II. Increases in direct, often polluted, overland runoff into surface watercourses

III. Reduction in river base flows and groundwater recharge

IV. Accelerated riverbank erosion and sedimentation 
V. Increases in river channel width and reduction in average water depth

VI. Increases in magnitude and frequency of flooding

VII. Increased scouring of bottom substrates and reduction in habitat for fish and fish food organisms

VIII. Elevated stream temperatures

IX. Loss of fish production and changes in fish species composition

Many landslides or flooding disasters are closely linked to rapid and unchecked urbanization which forces low-income families to settle on the slopes of steep hillsides or ravines, or along the banks of flood-prone rivers. When the total impervious area of a watershed is over 25 percent, serious degradation of downstream ecosystems has occurred (Department of the Interior, University of Wisconsin, 2002). The total amount of impervious area varies by the type of development. Studies have indicated the following range of values for the percentage of impervious area, based on the type of development:

I. High-density single family, multiple family, and high-rise residential: 30-65 percent

II. Schools and institutional use: 35-39 percent

III. Industrial: 70 percent

IV. General commercial (office parks, strip malls, shopping centers): 70-90 percent

V. Downtown commercial: $>95$ percent

Many landslide victims in urban areas have been impoverished due to sites failure rather than their houses. As population continues to grow, settlements spread to marginal and even unsafe areas. The rural-urban dichotomy by Umberto Di Giorgi, (1977) in his article titled 'Why Poor People Stay Poor' strongly maintains that the most important class struggle in the poor countries is not between capital and labour, or national and foreign interests, but between rural and urban classes. Undoubtedly, various objections could be made to this theory. For example, it might be considered that, in the last analysis, the conflict pinpointed by Lipton is closely linked with the conflict between capital and labour.

\section{Methodological approach}

For this study, after the selection and defining of the study area in term of spatial area, three major sources of data sets were identified, that is, ancillary data, satellite data, and ground truthing information. The satellite data acquired for this study are the Landsat TM and the Nigeria Sat 1which was subjected to Digital image processing and analysis. While under the spatial data, the direct field observation and measurement were carried out on the developmental activities within the area. The secondary (ancillary) data sources acquired include; the topographical maps used for study are the Lokoja sheet no. $147 \mathrm{NW}$ and 147 SW.

\section{Field data collection and ground truthing}

Ground reference data for training statistic and accuracy assessment were obtained through field observations. According to Lilles and and Kiefer (1987), field data collections (ground truthing) include image reading and measurement. Image reading is the identification of features using interpretation elements such as tone, pattern, shape, location or size. While image measurement deals with the extraction of numerical data by dimensioning identified ground reference features within the study area. And for the geo-referencing, Geographical Positioning System (GPS) Gacium 76 model and a Digital camera with zoom lenses were used to select major reference points within the town. The three Remote Sensing and GIS software used in the study are Arc View 3.3 and Idrisi 3.2. Arc View is more amenable in image manipulation than in Idrisi software, Ojigi, (2005).

Remote sensing and GIS analysis of development pattern in the area.

The two Landsat (TM and ETM) images acquired for this study were taking in 1987 and 2001 in order to carryout change detection and the assessment of the urbanization pattern around the confluence area. Fig. 2 and 3 shows the original imageries that were windowed from the two image full scenes. The variation in colouration of the images can be attributed to the time of imaging and the difference in payload.

\section{The urban land/use - land/cover mapping and development pattern in the town}

The unsupervised image classification of Landsat TM (1987) of this study area reveals that $20.16 \%$ of the total land is bare while $5.80 \%$ were built up. The bare surfaces in this image is high because the image was taken in December $21^{\text {st }}$ which is a dry season period when most part of the area had been subjected to bush burning. The hilly part of the area and the rivers (confluence area) covered about $23.05 \%$ and $5.34 \%$ respectively. While the vegetal areas was about $38.70 \%$ and the sand bars covered as much as $6.95 \%$ of the total 
land due to the silting nature of the river especially the Benue rive, see table. 2 for the 1987 and 2001 classified image.

The built up areas almost double in size with an additional area of 986.97 hectares, while the bare surfaces reduced by 1272 hectares. The reduction in the bare surfaces can be attributed to the variation in season, that is the dry season image of 1987 and the wet season image of 2001 which can also be explained off by the increase in the vegetation cover of about 3875.69 hectares. The river course also increases in width rather than volume due to bank erosion and depositional activities around this confluence area. The hills and the sand bars decreased in size by 362.51 and 352.68 hectares respectively due to human activities that is most noticeable on Patti hill.

\section{Findings}

Generally, an empirical study like this should highlight a number of observations from the field observation to the laboratory analysis and interpretation of results. Therefore the following major challenging issues were found out in the course of the study.

i. That spatial development are presently spreading toward Kabba and Ganaja roads as shown in most of the figures in this work.

ii. Land reclamation for various types of land use is on the increase along the Niger River especially in the current dualization of Filele road (Ibro market road).

iii. The image analysis and even visual observation reveal that Patti hill is being taken over by all forms of human development especially residential. The eastern side of Patti hill is subjected to slope failure year in year out due to human development.

iv. The aquatic eco-system within the river course and islands are given way to different dry season farming and other related activities.

v. There is general expurgation of many first and second order river channels which under natural conditions, played major role in keeping both sediment and runoff among many small channels which also plays its part in delaying movement of flood peak.

vi. Development activities around the catchment areas of River Mimi have changed the river regime and the shape of the river course.

\section{Conclusion}

Conclusively, it is obvious that the unique nature of this confluence area continually attracts the sitting of political seats in this town even after the departure of the colonial masters. But the enclosed nature of the town within the Patti ridge and the Niger River coupled with the influx of people to the state capital that causes the scramble and partitioning of finite land which brought about the encroachment problems in the town.

\section{Recommendations}

This study has so far demonstrate some of the potentials of RS and GIS technology in assessing the spatial pattern of urbanization in Lokoja on the confluence environment and therefore gives the following suggestions to ameliorate the obvious latent problems in the area:

The government of Kogi State should call a "spade-a-spade" and relocate all the major government activities to the new secretariat area.

The government should create more enabling environment for stringent implementation of the development control laws in the state particularly with the new master plan in place.

Apart from relocating the major governmental offices to the western side of Patti hill, the new market and other major commercial centres should be relocated to the same area in order to reduce the land use pressure at the core areas of the town.

Patti hill needs to be protected by stringent laws that can discourage all forms of terrace development activities on the slope to reduce the frequent occurrences of landslide.

Human capacity building in the area of RS and GIS should be one of the states priorities if the state capital environment is to be sustained. Development plans should be prepared ahead of land vendors in order to prevent haphazard development that is common in peri-urban areas.

\section{References}

Ferreira, J. and Wiggins, L. (1993). Computing Technology for Land Use and Regional Planning, in R. E. Klosterman and S. P French (Editors) Third International Conference on Computers in Urban Planning and Urban Management, Georgia Institute of Technology, Atlanta, GA, pp. 285.

Lillesand, T.M, and Kefers, R.W, (1987). Remote Sensing and Image Interpretation, $2^{\text {nd }}$ Edition, John Wiley \& sons Inc, London and New York, p.721

Langhelle, O., 1999. Sustainable development: exploring the ethics of Our Common Future. 
International Political Science Review 20 (2), 129 -149 .

Maurice A. (2005)'Hot Lokoja has its cool shades too', in The Sun News Online, Thursday, March 17

Obateru (2004). The Genesis And Future of Abuja. Penthouse publications (Nig.), first edition, pp 11, 22-37.

Ojigi, M.L, (2005). Digital Terrain Modeling and Drainage Analysis of the northern part of Abuja phase ii Development area, using Geospatial Techniques. A PhD thesis in the Department of Geography Remote Sensing Unit of Federal University of Technology, Minna, Nigeria. Pp115141.

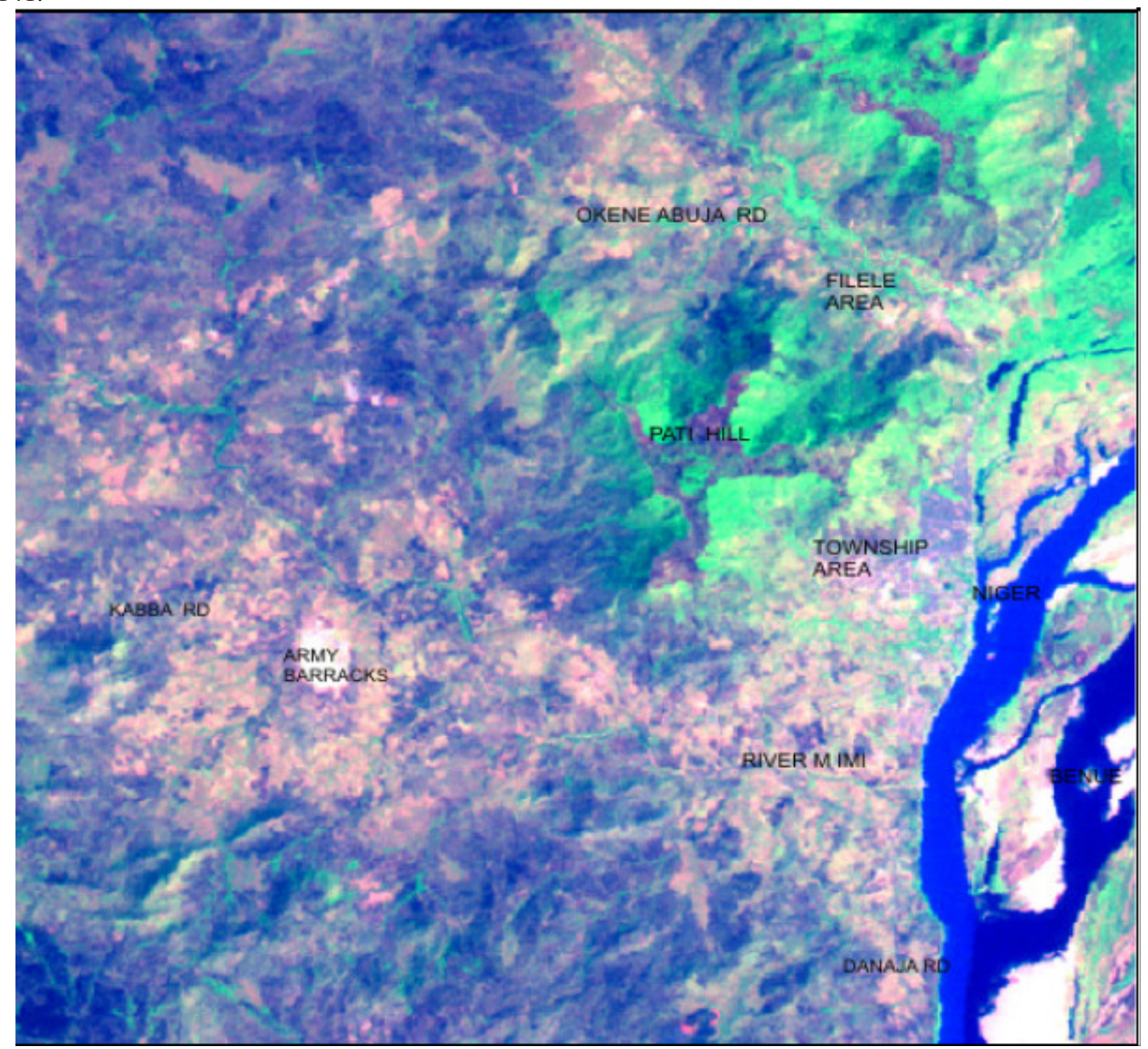

Figure 2 lokoja Town on LANDSAT (TM BANDS 2, 4, 5) IN 1987
Ononiwu, U, (1990). Effective management of River Basin by the use of Spot Imagery', in the $1^{\text {st }}$ Biennial National Hydrology symp.Pro. of the Nigerian National Committee for the Int. Hydrological Programme (IHP) in Maiduguri, P129-148.

U.S. Geological Survey (USGS), Department of the Interior. 2004a. The Effects Of Urbanization on Water Quality: Urban Runoff. Washington D.C.: USGS . 


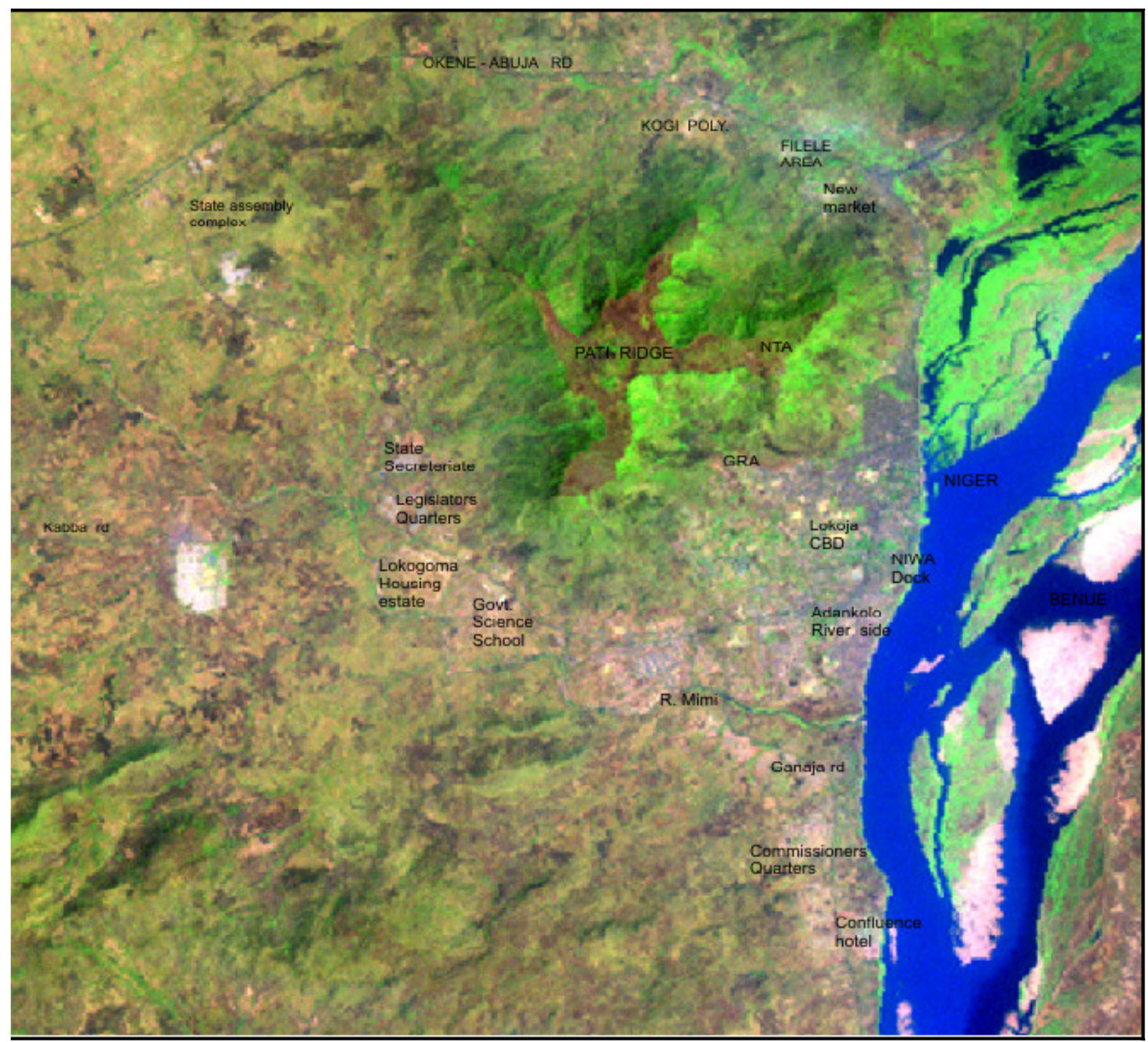

Figure 3 Lokoja Town on Landsat (TM Bands 2, 4, 5) in 2001

Table 2 Land use change detection in Lokoja area

\begin{tabular}{clccc}
\hline SN & Land uses & Hectares (1987) & Hectares (2001) & \multicolumn{1}{c}{ Changes +/- } \\
\hline 1 & Settlements & 1606.87 & 2593.84 & $986.97(+)$ \\
2 & Bare Surfaces & 5583.16 & 1355.16 & $1272(-)$ \\
3 & Vegetation & 10714.31 & 14590.93 & $3875.69(+)$ \\
4 & River & 1477.16 & 1556.76 & $79.44(+)$ \\
5 & Hills & 6382.42 & 6019.91 & $362.51(-)$ \\
6 & Sand Bars & 1923.08 & 1570.4 & $352.68(-)$ \\
& Total & 27687 & 27687 & \\
\hline
\end{tabular}

$(+)=$ increase in area $\quad(-)=$ decrease in area




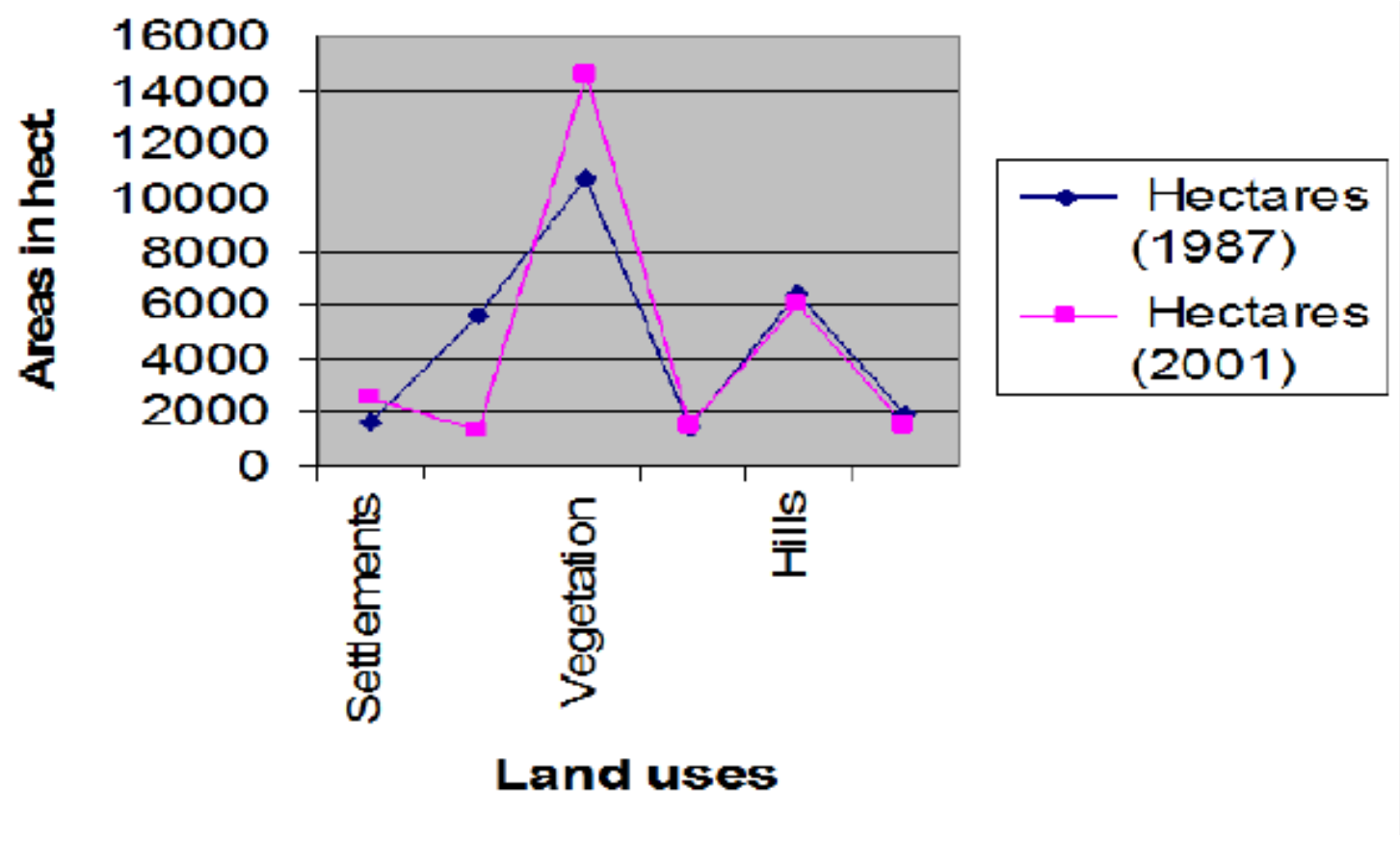

Figure 4 Land use/Land cover change line graph of Lokoja town between 1987 and 2001

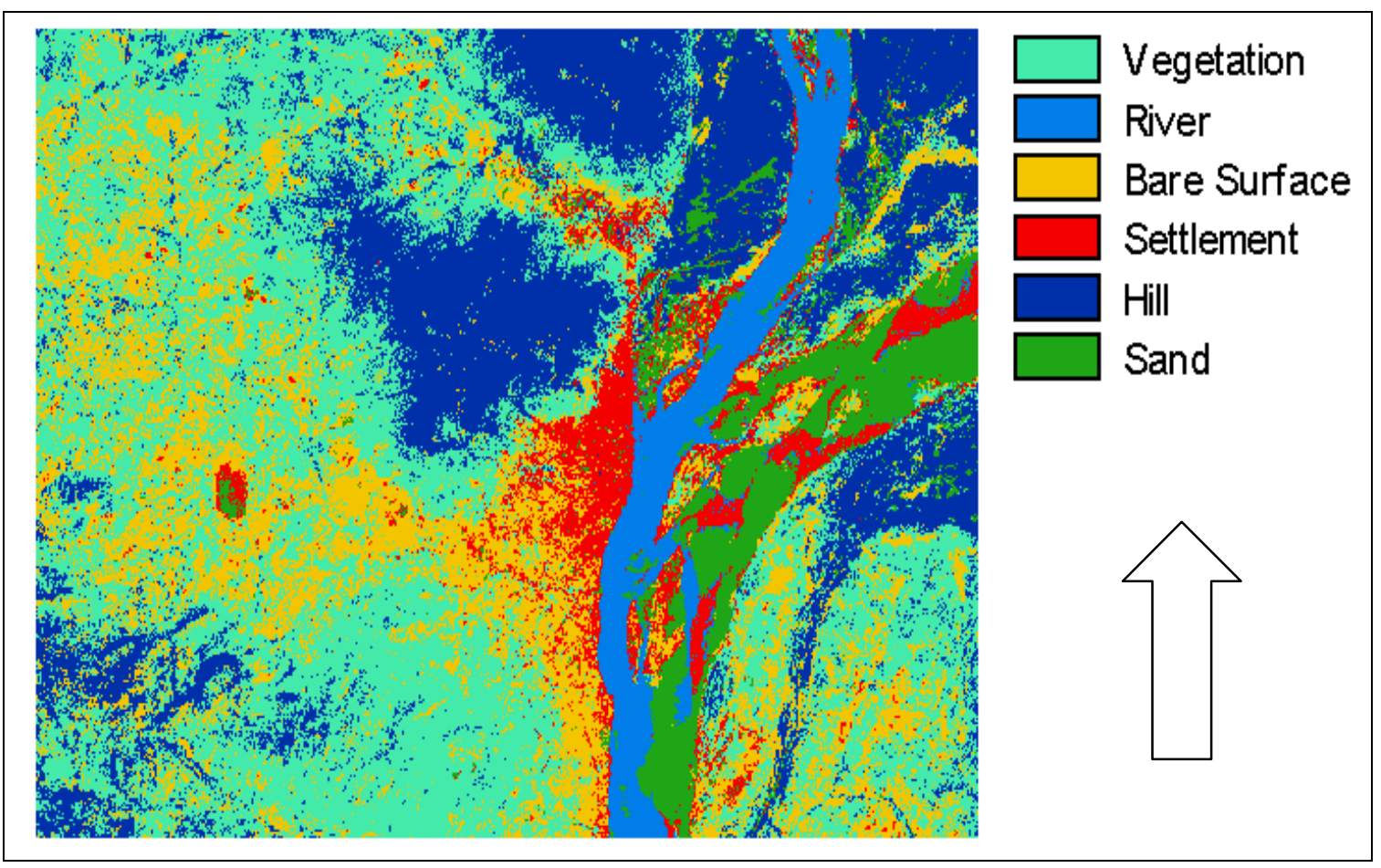

Figure 5 Land use classification of Lokoja area on Landsat image 1987 
Ethiopian Journal of Environmental Studies and Management Vol. 6 No.3 2013

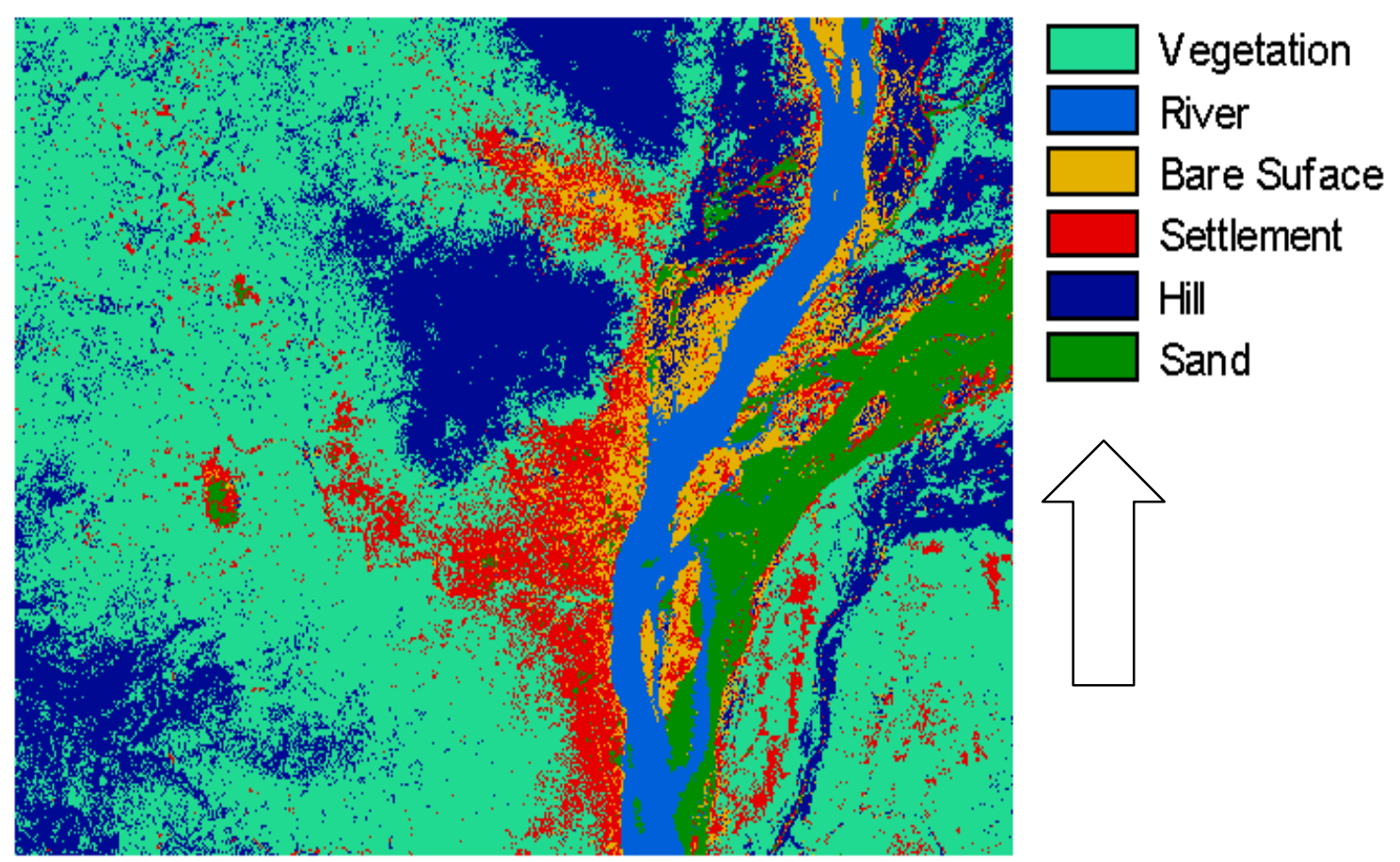

Figure 6 Land use classification of Lokoja area on Lansat image 2001 